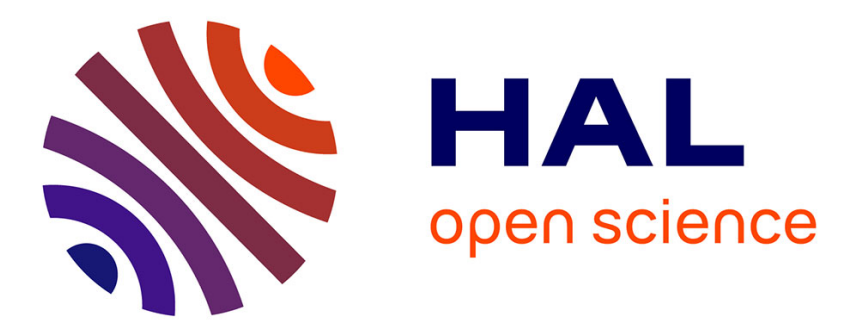

\title{
Basking African striped mice choose warmer locations to heat up: evidence from a field study
}

\author{
M. Zduniak, Neville Pillay, Carsten Schradin
}

\section{To cite this version:}

M. Zduniak, Neville Pillay, Carsten Schradin. Basking African striped mice choose warmer locations to heat up: evidence from a field study. Journal of Zoology, 2019, 309 (2), pp.133-139. 10.1111/jzo.12687 . hal-02169446

\section{HAL Id: hal-02169446 \\ https://hal.science/hal-02169446}

Submitted on $20 \mathrm{Jul} 2020$

HAL is a multi-disciplinary open access archive for the deposit and dissemination of scientific research documents, whether they are published or not. The documents may come from teaching and research institutions in France or abroad, or from public or private research centers.
L'archive ouverte pluridisciplinaire HAL, est destinée au dépôt et à la diffusion de documents scientifiques de niveau recherche, publiés ou non, émanant des établissements d'enseignement et de recherche français ou étrangers, des laboratoires publics ou privés. 
1 Short title: Basking spot preferences of African striped mouse

2

3

4 Title: Basking African striped mice choose warmer locations to heat up:

5 evidence from the field study.

6

$7 \quad$ Published as

8 Zduniak, M., Pillay, N. \& Schradin, C. 2019. Basking African striped mice choose

9 warmer locations to heat up: evidence from a field study. Journal of Zoology, 309, $10 \quad 133-139$.

11

12

13 Milena Zduniak, Neville Pillay, Carsten Schradin

14

15

16

17 Adam Mickiewicz University, Department of Systematic Zoology, Umultowska 89, 61-614

18 Poznań, Poland (MZ)

19 University of the Witwatersrand, School of Animal, Plant and Environmental Sciences,

20 Private Bag 3, WITS 2050, Johannesburg, South Africa (MZ, NP, CS)

21 IPHC, UNISTRA, CNRS, 23 rue du Loess, 67200 Strasbourg, France (CS)

22

23

24 Corresponding author : Milena Zduniak, zdun@amu.edu.pl

25 
29 Basking in the sun is an important energy saving tactic in ectotherm animals. It has also been recognized to be important in several mammal species, especially in arid environments. In particular, small mammals which have a greater surface-to-volume ratio can use basking to reduce metabolic energy expenditure by using external heat to maintain a high body temperature. If basking mainly functions to passively gain heat, animals should choose basking spots that offer a more favorable micro-climate for warming up. We tested this hypothesis in African striped mice (Rhabdomys pumilio), a diurnal species that is known to bask. Over 19 months, we displaced 138 individuals from their basking spots and immediately thereafter measured the temperature of the surface $\left(T_{0}\right)$ at the spots. We expected that striped mice choose spots for basking that are warmer than random spots, especially in a) the morning, when $\mathrm{T}_{\mathrm{o}}$ is lower compared to afternoon, and $\mathrm{b}$ ) in the dry season characterized by low food availability in which energy gain due to basking is more beneficial than in the moist season with high food availability. Moreover, we tested whether there are differences in relative safety (measured as available plant cover) at basking spots compared to random spots. $\mathrm{T}_{\mathrm{o}}$ was significantly higher at basking spots than at random spots. However, we did not find any differences in $\Delta \mathrm{T}$ in relation to season, time of the day or in the safety between basking and random spots. In conclusion, our study indicates that striped mice choose basking spots with a favourable microclimate characterized by higher ambient temperature. 
Animals inhabiting extreme arid environments display physiological and behavioural adaptations to harsh thermal conditions and scarce food (Rymer et al 2016). This makes themalso vulnerable to climate change. The most dramatic examples come from Australia where heat waves caused mass fatalities in birds and bats (McKechnie and Wolf 2009, Ratnayake et al. 2019). Baseline knowledge on how animals cope with challenging thermal conditions via physiological and behavioural plasticity is essential to predict future changes in animal communities in arid ecosystems (Huey et al. 2012, Mitchell et al. 2018). Endothermic animals spend a significant amount of their energy maintaining a relatively stable and high body temperature. This can be challenging when ambient temperatures are low and food becomes scarce (Brown and Downs 2005). Thermoregulation

64 is especially costly for small animals because they have a high surface-to-volume ratio and 65 high metabolic rate. To cope with these challenges, they use different strategies for energy 66 saving (Terrien, Perret and Aujard 2011, Cossins, 2012). Some have developed physiological 67 adaptations such as entering torpor or hibernation (Humphries et al 2002). Others adjust their behaviour by resting in nests to avoid adverse thermal conditions (Glaster and Lustick 1975, Morton 1978), huddling with conspecifics to reduce heat loss (Gilbert et al. 2010, Schradin et al. 2006), intensifying locomotor or foraging activity to produce endogenous heat (Ishii et al. 71 1996, Brobeck 1948), and basking in the sun to warm up passively (Mzilikazi, Lovegrove and 72 Ribble 2002, Warnecke and Geiser 2010, Brown and Downs 2007). While basking behaviour 73 has long been studied in detail in ectotherms, such as insects and reptiles (O'Neill and Rolston 74 2007, Bennett et al. 2014, Herrera 1995, Row and Blouin-Demers 2006, Webb and Whiting 75 2005), it only recently received attention as an important tactic in mammals (Mzilikazi et al. 2002, Geiser and Drury 2003, Warnecke and Geiser 2010, Geiser et al. 2017). 
In mammals, basking has been frequently observed in arid habitats with scarce

78 vegetation, and where solar radiation is easily accessible and thus provides a reliable source of energy. Basking in the sun is used by small mammals to save internal energy when arousing from torpor, as occurs in rock elephant shrews (Elephantulus myurus, Mzilikazi et al. 2002) and in several species of small marsupials (Warnecke et al. 2008 and 2010, Warnecke and Geiser 2010, Stannard, Fabian and Old 2015, Jastroch et al. 2016). Basking also occurs in diurnal mammals that do not hibernate or enter into torpor. Several species of small mammals bask in the morning when ambient temperature $\left(\mathrm{T}_{\mathrm{a}}\right)$ is much lower than their thermoneutral zone (defined as temperature in witch metabolic costs of sustaining constant body temperature are the lowest; Brown and Downs 2006, Scantlebury et al. 2006) to compensate for heat loss. Basking is regularly observed in dassie rats (Petromus typicus, Rathbun and Rathbun 2006) and rock hyraxes (Procavia capensis, Brown and Downs 2005). Thus, basking is an important energy saving strategy of many small mammal animal species and we therefore expect that they choose basking spots that are optimal for energy saving.

The thermal microclimate influences the behaviour of heterotherms. For instance, the space use of Taylor's checkerspot butterflies (Euphydryas editha taylori) is shaped by access to sunlight (Bennett, Betts and Smith 2014). Grasshoppers choose different vegetation levels depending on time of the day to regulate body temperature (O'Neill and Rolston 2007). Foraging activity of bees increases significantly with ambient temperature $\left(\mathrm{T}_{\mathrm{a}}\right)$, while basking frequency decreases (Herrera 1995). Similarly, in reptiles, microhabitat differences in the thermal environment affect basking opportunities and ultimately behaviour and reproduction (Aguado and Brana 2014; Schwarzkopf and Shine 2006). Basking spot choice might influence how effectively individuals are able to save energy. Since basking is a strategy to passively heat up, the warmer the spot, the faster animals will be able to heat up. Thus, the temperature of the basking spot could be a crucial factor in its choice. Ambient temperature as well as the 
102 object $\left(\mathrm{T}_{0}\right)$ on which basking occurs can vary significantly within a small spatial scale,

103 depending on, for example, substrate type, slope, orientation, surrounding vegetation and

104 humidity (Viles 2005). We therefore predicted that animals might choose basking spots with a

105 warmer microclimate.

106 Behavioral thermoregulation has been observed in several mammalian species. Yellow

107 baboons (Papio cynocephalus) change their body postures depending on solar radiation and

108 wind direction (Stelzner and Hausfater 1986). Rock hyraxes adjust their positions while

109 basking, which was affected not only by the temperature but also by antipredatory vigilance

110 and social interactions (Brown and Downs 2007). Spotted hyenas (Crocuta crocuta) also

111 account for both safety and thermoregulatory needs while choosing resting spots (Kushata et

112 al. 2018). However, little is known about how mammals choose basking sites and whether

113 they purposely choose locations with a warmer microclimate.

114 Our study model is the African striped mice (Rhabdomys pumilio), a diurnal semi-arid

115 resident. The behaviour of striped mice is influenced by basking opportunities, which become

116 active earlier on sunny days (Schradin et al 2007). Scantlebury et al. (2010) found that within

117 a metabolic chamber, oxygen consumption of striped mice decreased in direct sunshine

118 compared with in the shade. This effect occurred independently of the ambient temperature

$119\left(\mathrm{~T}_{\mathrm{a}}\right)$, indicating that a significant amount of radiant energy was absorbed from the sun. This

120 previous study thus found that metabolic rate is reduced when i) ambient temperature

121 increases; and ii) striped mice are directly exposed to radiation (controlling for $\mathrm{T}_{\mathrm{a}}$ ).

122 Here we tested whether African striped mice (Rhabdomys pumilio) choose basking

123 spots that have a higher $\mathrm{T}_{\mathrm{o}}$ (the object used to bask on). than random spots, to assess the

124 microhabitat preferences of striped mice. Striped mice bask extensively in the morning and in

125 periods when food availability is low (Schradin et al. 2007), which allows them to reduce

126 their metabolic rate and save energy (Scantlebury et al. 2010). Thus, we further expected that 
127 microhabitat choice is more important when $\mathrm{T}_{\mathrm{o}}$ is low in the morning compared to the

128 afternoon, when $T_{0}$ is higher and close to the thermoneutral zone of striped mice (i.e.,

129 Scantlebury et al. 2006). Further, we expected striped mice to choose relatively warmer

130 basking spots in the dry season, when food availability is lower and thus energy saving more

131 important, than in the food rich moist season (Schradin et al. 2007, Warnecke et al. 2010).

132 Finally, we also tested whether basking spots might be surrounded with more accessible plant

133 cover than random spots, which we assumed to be a measure of safety.

134

135

136

137

138

139

140

141

142

143

144

145

146

147

148

149

150

151

\section{MATERIAL AND METHODS}

\section{Study site and period}

We collected data for 19 months between February 2016 and August 2017 in Goegap Nature Reserve, Northern Cape, South Africa. Our study site is located at an elevation of $950 \mathrm{~m}$ above sea level in a sandy, episodic river valley and surrounded by rocky hills.

Vegetation is typical for the Succulent Karoo, dominated by ever-green shrub Zygophyllum retrofractum, with many species of small succulents and annual plants in spring. The climate is semi-arid, characterized by moist winters and springs (May-November) and dry and hot summers and autumns (December-April). Temperatures at the field site vary between $-5.0^{\circ} \mathrm{C}$ and $24^{\circ} \mathrm{C}$ in winter and $5^{\circ} \mathrm{C}$ and $44^{\circ} \mathrm{C}$ in summer. The study was conducted during very dry years with an average rainfall of $1.44 \mathrm{~mm} /$ month and a maximum value of $10 \mathrm{~mm} / \mathrm{month}$ in June 2017, which was clearly below the average recorded in $2005-2017$ (13.83 mm/month).

We used data from plant surveys to define seasons. Vegetation is a good proxy for denoting the moist season because plant growth depends on more frequent and regular rainfall. High plant availability also affects the onset of reproduction and foraging behaviour of striped mice (Schradin and Pillay 2004). We conducted plant surveys twice a month, determining the number of food plants in 8 monitoring plots of $4 \mathrm{~m}^{2}$ each. Months with a $>5$ average number 
152 of vegetating food plant species per month were regarded as moist season, since we know that

153 at such high food availability there is no physiological indication of food shortage in striped

154 mice (blood glucose levels are high and blood ketone levels are low; Schradin unpubl. data).

Measuring $T_{o}$ at basking and random spots and $T_{\min }$

afternoons. We waited for individuals to emerge from the nest or return from foraging to bask.

160 An observer sat still and quiet 5 to 10 meters away from the nest. Such close observations were possible without disturbing natural behavior of mice, since the population had been constantly studied for 15 years and striped mice are habituated to the presence of human observers. We identified individuals by specific dye markings applied to the fur of striped

164 mice during previous trapping (Schradin and Pillay 2004). We carefully recorded the basking

165 location of a mouse (using binoculars when necessary) and walked towards the spot (chasing

166 the mouse away) to measure $T_{0}$ of the basking spot. $T_{0}$ is the temperature of the object or

167 surface on which animal was seen basking, such as sand, plants or stones, and can be affected

168 by factors, such as solar radiation (directly or reflected from the sun), conduction, convection,

169 evaporation, material composition (Cossins 2012). Due to these factors. $T_{0}$ can vary on a

170 small scale and provide unique thermal conditions to basking animals.

171 To was measured with a Powerfix infrared temperature probe (infrared gun;

172 Kompernass Handels GmbH, Bochum, Germany; Laser class 2, 650nm) with a reported 173 accuracy of $2 \%$. After the measurement was taken, we took measurements at two random 174 spots. The first was approximately $20 \mathrm{~cm}$ (measured with the length of the infrared gun) to the 175 right of the basking location (if this was not possible due to impeding vegetation cover, the 176 measurement was taken to the left). The second random spot was approximately $20 \mathrm{~cm}$ in 
177 front of the basking spot in the open and away from the shrub. All measurements were taken

178 in the sun. All procedures needed for behavioural observations were conducted following

179 protocols approved by the Animal Ethics Screening Committee of the University of the

180 Witwatersrand (AESC 2012/37/2A, AESC 2014/40/B) and in accordance with Guidelines for

181 the treatment of animals in behavioural research and teaching (Vitale et al. 2018).

182 Fifty basking spots and their random spots (right and front) were temporarily marked

183 after temperature measurement was taken. On the following day, all measurements were

184 repeated at the exact same time but without a mouse being been present directly before the

185 measurement, and this was again compared to random spots. We did this to exclude the

186 possibility that higher temperatures at basking spots were due to the mouse`s body heat

187 having heated up the spot, rather than due to microclimate differences.

188 Minimum daily temperature $\left(\mathrm{T}_{\min }\right)$ was taken every day at the research station, located

$189300 \mathrm{~m}$ away from the study site. We used an electronic thermometer with an accuracy of

$1900.1^{\circ} \mathrm{C}$, and measurements were recorded every morning $10 \mathrm{~cm}$ above the ground.

191

Plant cover measurements to characterise basking spots

193

194 We marked 61 spots at which we observed mice basking more than once and marked these

195 locations with small flags. For each of these basking locations, we marked a control spot 20

$196 \mathrm{~cm}$ to the right at the same bush. We made sure that these random spots were not used as

197 basking spots by observing them for a few consecutive days. We measured plant cover at both

198 spots as a proxy of protection from predators. We created a cover index of 0 to 4 by

199 considering cover to the left, right, above and behind the marked spot. We summed the score

200 of plant cover for each spot. Thus, a spot received a score of 4 when it had cover on all four

201 sides, 3 for cover on three sides and so on. 

observation to a season (dry or moist) and time of the day (morning or afternoon). 204 of our observations were conducted in the morning and 166 in the afternoon. 305 observations took place in dry season and 65 in the much shorter moist season (September-December 2016 and August 2017); this disproportion is due to the fact that the moist season in the Succulent

210 Karoo is generally much shorter than the dry season and rainfall during our study period was 211 especially low.

212 We analysed data in $\mathrm{R}$ version 1.0.136 using basic descriptive statistics with the stats 213 package and linear mixed models implemented in the lme4 package (lmer function; Bates,

214 Maechler and Bolker, 2015). To exclude the possibility that basking spots were warmer due to

215 mouse body heat we compared $\mathrm{T}_{\mathrm{a}}$ with the mouse being present or not present before the

216 measurement (paired data, Wilcoxon matched-pairs sign rank text), and by comparing

217 correlation coefficients of 1) temperatures taken at basking spots with a striped mouse being

218 present and not present before a measurement, and 2) repeated temperature measurements

219 taken with the mice absent on the following day, using Fisher-Z transformation.

220 We ran 2 separate linear mixed models for morning and afternoon data. Object

221 temperature was included as the response variable and spot category (basking spot, right and

222 front random spots), and season (moist or dry) were used as explanatory variables. We also

223 included individual and nest as random factors.

224 We investigated factors that affected the temperature difference $(\Delta T)$ between basking 225 spots and the right random spot. We chose $\Delta \mathrm{T}$ values based on the right spot as the response 226 variable in our model because it was taken at the bush, not in the open and thus it had similar 
thermal properties and plant cover. In addition, the front spot included several outliers and had

228 greater variation and were not suitable for analyses. We used $\Delta \mathrm{T}$ as a response variable in a

229 linear mixed model and included time of the day (morning or afternoon), season (dry or

230 moist) as fixed factors and daily minimum temperature as a continuous factor. Individual and

231 nest were added as random factors. Finally, we compared the cover index of basking spots

232 compared to non-basking spots (index of 0-4) using paired Wilcoxon test.

\section{RESULTS}

$\mathrm{T}_{\mathrm{o}}$ at basking spots was significantly higher in the afternoon $\left(28.2 \pm 5.7^{\circ} \mathrm{C}, \overline{\mathrm{X}} \pm \mathrm{SE}\right)$ than in the morning $\left(16.1 \pm 4.6^{\circ} \mathrm{C} ; \mathrm{t}=22.59, \mathrm{df}=368, \mathrm{P}<0.001\right.$, unpaired $\mathrm{t}$-test $)$. $\mathrm{T}_{\mathrm{o}}$ did not differ between basking spots in the dry $\left(21.8 \pm 7.6^{\circ} \mathrm{C}\right)$ and moist season $\left(20.1 \pm 9.0^{\circ} \mathrm{C} ; \mathrm{t}=1.58, \mathrm{df}=368\right.$ $\mathrm{P}=0.11$, unpaired t-test).

There was no significant difference in $\mathrm{T}_{\mathrm{o}}$ when mice were present $\left(22.7 \pm 8.3^{\circ} \mathrm{C}\right)$ or absent $\left(24.3 \pm 8.5^{\circ} \mathrm{C}\right)$; Wilcoxon-matched pairs sign rank test: $\left.\mathrm{V}=1136.5, \mathrm{P}=0.4359\right) . \mathrm{T}_{\mathrm{o}}$ taken after displacing a mouse from a basking spot was significantly and positively correlated with $\mathrm{T}_{\mathrm{o}}$ at the same basking spots on the next day without a mouse being present (Pearson correlation, $\mathrm{r}=0.95, \mathrm{P}<0.001)$. The second set of measurements comparing 2 temperatures at basking locations with mice being absent were significantly correlated (Pearson correlation $\mathrm{r}=0.94, \mathrm{P}<0.001)$. Fisher- $\mathrm{Z}$ transformation revealed no differences between these 2 correlation coefficients $(\mathrm{Z}=0.5, \mathrm{P}=0.62)$. higher than at the two random spots, both in the morning and in the afternoon (Fig.1). To also depended on the time of the day and minimum daily temperature, but not on the season (Table 1a and $1 b)$. 
252 between morning and afternoon $(\mathrm{P}=0.30)$ nor between moist and dry season $(\mathrm{P}=0.64)$. There

253 was no effect of minimum daily temperature on $\Delta \mathrm{T}(\mathrm{P}=0.12$, see also Table 2$)$.

254 The cover scores at basking spots were $2.30 \pm 1.15$ and $2.11 \pm 1.08$ at random spots.

255 Of the 61 basking spots where we took plant cover measurements, 19 basking spots had

256 greater cover scores than random spots, 13 basking locations had lower cover scores, and

257 there was no difference in 22 cases. Overall, we found no difference in cover scores between

258 basking and random spots (Wilcoxon matched-pairs sign rank test, $\mathrm{V}=306, \mathrm{P}=0.23$ ).

259

260

261

262

263

264

265

266

267

268

269

270

271

272

273

274

275

276

\section{DISCUSSION}

We found that striped mice bask at spots that have a warmer microclimate than random spots. In contrast, basking spots did not offer more cover from potential predators than random spots at the same bush. Also, $\Delta \mathrm{T}$ did not differ between seasons and between morning and afternoon. Striped mice bask to passively heat up and thus save metabolic energy (Scantlebury et al. 2010). Therefore, choosing basking spots with high $T_{0}$ would be adaptive. Our current results underline the importance of basking for striped mice that seem to purposely choose warmer basking spots.

We found that African striped mice use basking spots with higher temperature than random spots. Basking spots were warmer than random spots at the shrubs and in the open. Our data indicate that areas close to the shrubs had a warmer microclimate than those away from a shrub (the random spot to the right of a shrub was significantly warmer than the one in front), although they did not differ in terms of safety, indicating that between 2 spots with similar safety, mice chose the one with higher $\mathrm{T}_{0}$. Basking spots also had higher $\mathrm{T}_{\mathrm{o}}$ than random locations measured the following day without a mouse being present, indicating that it was not the presence of the basking mouse that would have heated up the basking spot. 
277 Thus, our results indicate that the temperature is a crucial factor affecting basking spot choice 278 in African striped mouse.

279 Even though mice chose warmer basking spots, we did not find clear patterns between

$280 \Delta \mathrm{T}$ and minimum daily temperature or season. Our results indicate that mice prefer warmer

281 spots for basking, but the difference between selected spots and random was rather subtle

282 (average difference between basking spots and random spots was lower than $2^{\circ} \mathrm{C}$ ). African

283 striped mice usually bask in front of the nest in which they spent the night (Schradin et al.

284 2007). It is possible that under natural conditions the access to optimal thermal locations for

285 basking is very limited, and thus it is energetically not worth traveling longer distances in

286 search of a warmer location. Instead animals pick the most favourable spots around their

287 nests.

288 Basking at exposed spots probably increases predation risk since it exposes striped

289 mice to visual predators, such as shrikes, birds of prey, wildcats and jackals, all of which are

290 known to prey frequently on striped mice in our study population (Schradin, unpubl. data).

291 The trade-off between basking and safety was previously described in reptiles (Carrascal et al.

292 1992, Carter, Goldizen and Tromp 2010, Meek et al. 2008, Web and Whiting 2005). Striped

293 mice chose basking locations that are warmer and also offered adequate protection against

294 potential predators, since these were are directly at shrubs. While basking spots offer the

295 option to quickly withdraw into the safety of the shrub should a predator approach, basking

296 spots did not offer more cover than random spots at the same shrubs. Thus, we did not find

297 that striped mice chose particularly safe basking spots, possibly because all spots at a shrub

298 offer sufficient cover to quickly hide in case of a predation event.

299 The selection of basking sites might be based not only on object temperature but also

300 on whether they adequately camouflage the basking animal. For example, Aegean wall lizards

301 (Podarcis erhardii) selected basking sites in which their dorsal surface better matched the 
302 background surface, providing camouflage against avian predators (Marshall et al. 2016).

303 Whether striped mice similarly selected basking sites that offered camouflage is currently

304 unknown; the stripes might have a dazzle effect creating confusion (Schradin

305 ENCYCLOPEDIA!, Stevens 2007). Moreover, mice also stay still (freeze) while basking

306 which is a common antipredatory behaviour in many species, protecting them from being

307 spotted by predators sensitive to visual motion (Bolles 1970, Stevens 2007). Basking in the

308 open is occasionally observed in striped mice but it is rather uncommon behaviour (Schradin,

309 unpubl. data). Therefore, with the relative safety provided by near a bush, it was more

310 important for animals to choose a spot with higher $T_{0}$.

311 It has only recently been recognized that basking is an important energy saving

312 strategy in mammals. Here we present one of the first studies demonstrating that mammals,

313 similar to reptiles or invertebrates, choose basking spots with a favourable microclimate for

314 basking. Several other factors might also influence basking spot choice such as proximity to

315 the nest or social factors (Brown and Downs 2007), and particularly predator avoidance and

316 ability to camouflage (Marshall et al. 2016). Striped mice bask at safe spots, from where they

317 can withdraw quickly into the safety of a shrub. However, while basking spots did not differ

318 in cover providing safety compared to random spots, they were warmer. This indicates that

319 basking spots are chosen in a way to maximize energy savings due to passively heating up

320 while being in a relatively safe location, which would represent an adaptive choice of basking 321 spots.

322 Our findings provide important insight into thermoregulatory behaviours of African

323 striped mice. This semi-desert species is known for its behavioural, physiological and social

324 adaptations that help it cope with harsh environmental conditions (Mallarino, Pillay, Hoekstra,

325 and Schradin 2018). However, the species is facing temporary size and population viability

326 declines due to more frequent droughts in the Succulent Karoo region (Nater et al. 2018). 
327 Temperature rise and droughts may also affect basking patterns in this and other arid species.

328 It is essential to understand the mechanisms shaping these thermoregulatory behaviours

329 predict future responses of species to challenges of climate change.

330 


\section{ACKNOWLEDGEMENTS}

333

334 We would like to thank all the people involved in data collection, Jessica Mulvey and

335 Dominik Schüßler for discussions and their input in the study design. We would also like to

336 thank Rafał Zwolak for his advice with statistical analyses. This study was made possible with

337 the support of the Succulent Karoo Research Station (registered South African NPO 122-134)

338 and Goegap Nature Reserve. This study was supported by the University of the Witwatersrand

339 and the CNRS. Animals were captured and handled following protocols approved by the

340 Animal Ethics Screening Committee of the University of the Witwatersrand (AESC

341 2012/37/2A extended until December 2019, AESC 2014/40/B).

342

343

344

345 Aguado S., Brana F., 2014. Thermoregulation in a cold-adapted species (Cyren's rock lizard

\section{REFERENCES}

Iberolacerta cyreni): influence of thermal environment and associated costs. Canadian Journal of Zoology 92:955-964. DOI:10.1139/cjz-2014-0096

Bates D., Maechler M.,Bolker B., Walker S., 2015. Fitting Linear Mixed-Effects Models

Using lme4. Journal of Statistical Software, 67(1), 1 -48. DOI:10.18637/jss.v067.i01

Bennett V.J., Betts M.G., Smith W.P. 2014. Influence of thermal conditions on habitat use by a rare spring-emerging butterfly Euphydryas editha taylori, Journal of Applied Entomology, 138:623-634. DOI:10.1111/jen.12137

Bristow, K. L. 1998. Measurement of thermal properties and water content of unsaturated sandy soil using dual-probe heat-pulse probes. Agricultural and Forest Meteorology, 89(2):75-84. DOI:10.1016/S0168-1923(97)00065-8 
357 Brown, K. J., Downs, C. T. 2006. Seasonal patterns in body temperature of free-living rock

358 hyrax (Procavia capensis). Comparative Biochemistry and Physiology Part A: Molecular and 359 Integrative Physiology, 143(1):42-49. DOI: 10.1016/j.cbpa.2005.10.020

360 Brown, K. J., Downs, C. T. 2007. Basking behaviour in the rock hyrax (Procavia capensis)

361 during winter. African Zoology, 42(1):70-79. DOI: 10.1080/15627020.2007.11407379

362 Carrascal, L. M., López, P., Martín, J., Salvador, A. 1992. Basking and antipredator behaviour

363 in a high altitude lizard: implications of heat exchange rate. Ethology, 92(2):143-154. DOI:

364 10.1111/j.1439-0310.1992.tb00955.x

365 Carter, A. J., Goldizen, A. W., Tromp, S. A. 2010. Agamas exhibit behavioral syndromes:

366 bolder males bask and feed more but may suffer higher predation. Behavioral Ecology,

367 21:655-661. DOI: 10.1093/beheco/arq036

368

369 Chown, S. L., Hoffmann, A. A., Kristensen, T. N., Angilletta Jr, M. J., Stenseth, N. C.,

370 Pertoldi, C., 2010. Adapting to climate change: a perspective from evolutionary

371 physiology. Climate Research, 43(1-2), 3-15. DOI: $10.3354 /$ cr00879

372 Cossins. A., Bowler, K., 2012. Temperature biology of animals. Chapman and Hall, London, 373 United Kingdom.

375 Geiser F., Drury R.L., 2003. Radiant heat affects thermoregulation and energy expenditure

376 during rewarming from torpor. Journal of Comparative Physiology B, 173:55-60. DOI:

$377 \quad 10.1007 / \mathrm{s} 00360-002-0311-\mathrm{y}$

378

379 Geiser, F., Stawski, C., Wacker, C. B., Nowack, J. 2017. Phoenix from the Ashes: Fire, Torpor, 380 and the Evolution of Mammalian Endothermy. Frontiers in Physiology, 8:842. DOI: 
382

383 Gilbert C., McCafferty D., Le Maho Y., Martrette J.-M., Giroud S., Blanc S., Ancel A. 2010.

384 One for all and all for one: the energetic benefits of huddling in endotherms, Biological

385 Revisions 85:545-569. DOI: 10.1111/j.1469-185X.2009.00115.x.

386

387 Glaster H., Lustick S. 1975. Energetics and nesting behavior of northern white-footed mouse

388 (Peromyscus leocopus-noveboracensis). Physiological Zoology 48(2):105-113. DOI:

$389 \quad 10.1086 /$ physzool.48.2.30155644

390

391 Vitale A., Calisi R., Carere C., Carter T., Ha J. C., Hubrecht R., Jennings D., Metcalfe A.,

392 Ophir G., Ratcliffe J. M., Roth T. C., Smith A., Sneddon L. 2018. Guidelines for the Use of 393 Animals. Guidelines for the treatment of animals in behavioural research and teaching 2018.

394 Animal Behaviour 135(2018):I-X. DOI:

395

396

397 Herrera C.M., 1995. Floral biology. Microclimate and pollination by ectothermic bees in an 398 early-blooming herb. Ecology 76:218-228. DOI: 10.2307/1940644

Huey, R. B., Kearney, M. R., Krockenberger, A., Holtum, J. A., Jess, M., \& Williams, S. E., 2012. Predicting organismal vulnerability to climate warming: roles of behaviour, physiology

402 and adaptation. Philosophical Transactions of the Royal Society B: Biological Sciences, $403 \quad 367(1596), 1665-1679$

404

405 Humphries M. M., Thomas D. W., Speakman J. R. 2002. Climate-mediated energetic 
constraints on the distribution of hibernating mammals. Nature. 418(6895):313-316. DOI: 10.1038 /nature 00828

Ishii K., Kuwahara K., Tsubone H., Sugano S. 1996. The telemetric monitoring of heart rate, locomotor activity and body temperature in mice and voles (Microtus arvalis) during ambient temperature changes. Laboratory Animals, (1):7-12. DOI: 10.1258/002367796780744992

Jastroch M., Giroud S., Barrett P., Geiser F., Heldmaier G., Herwig A. 2016. Seasonal control of mammalian energy balance: recent advances in the understanding of daily torpor and hibernation. Journal of Neuroendocrinology, 28(11). DOI: 10.1111/jne.12437

\section{Kushata J. N. T., Périquet S., Tarakini T., Muzamba M., Mafuwa B., Loveridge A. J., Valeix} M., 2018. Drivers of diurnal rest site selection by spotted hyaenas. Journal of Zoology, 304(2). DOI: 10.1111/jzo.12504.

Marshall, K.L., Philpot, K.E. and Stevens, M., 2016. Microhabitat choice in island lizards enhances camouflage against avian predators. Scientific Reports, 6, p.19815.

McKechnie, A. E., \& Wolf, B. O. (2009). Climate change increases the likelihood of catastrophic avian mortality events during extreme heat waves. Biology letters, 6(2), 253-256

Meek R., Avery R.A., 2008. Basking in the Australian water dragon Physignathus lesueurii; why do alpha males not respond to operative temperatures in the same way as adults and subadults? Amphibia-Reptilia, 29, 257-262. DOI: 10.1163/156853808784125009 
431 Mitchell, D., Snelling, E. P., Hetem, R. S., Maloney, S. K., Strauss, W. M., \& Fuller, A.

432 (2018). Revisiting concepts of thermal physiology: Predicting responses of mammals to 433 climate change. Journal of Animal Ecology, 87(4), 956-973.

434

435 Morton S. R.,1978. Torpor and nest sharing in free-living Sminthopsis crassicaudata

436 (Marsupialia) and Mus musculus (Rodentia). Journal of Mammalogy 59(3):569-575. DOI:

$437 \quad 10.2307 / 1380234$

438

439 Mzilikazi M., Lovegrove B.G., Ribble D.O., 2002. Exogenous passive heating during torpor 440 arousal in free-ranging rock elephant shrews Elephantulus myurus. Oecologia 133. DOI:

$441 \quad 10.1007 / \mathrm{s} 00442-002-1052-\mathrm{z}$

442

443 O'Neill K.M., Rolston M.G., 2007. Short-term dynamics of behavioral thermoregulation by 444 adults of the grasshopper Melanoplus sanguinipes. Journal of Insect Science 7. DOI:

$445 \quad 10.1673 / 031.007 .2701$

446

447 O'Shea, T. J., Cryan, P. M., Hayman, D. T., Plowright, R. K., \& Streicker, D. G. (2016).

448 Multiple mortality events in bats: a global review. Mammal Review, 46(3), 175-190

449

450 Porter, K., 1982. Basking behaviour in larvae of the butterfly Euphydryas aurinia. Oikos, $451 \quad 38: 308-312$. DOI: $10.2307 / 3544670$

452

453 Rathbun G.B., Rathbun C.D., 2006. Sheltering, basking and petrophily in the noki or dassie454 rat (Petromus typicus) in Namibia. Mammalia 70(3-4):269-275. DOI:

$455 \quad$ 10.1515/MAMM.2006.038 
456 Ratnayake, H. U., Kearney, M. R., Govekar, P., Karoly, D., \& Welbergen, J. A., 2019.

457 Forecasting wildlife die-offs from extreme heat events. Animal Conservation. Online first 458 https://doi.org/10.1111/acv.12476

459

460 Row J.R., Blouin-Demers G., 2006. Thermal quality influences effectiveness of

461 thermoregulation, habitat use, and behaviour in milk snakes. Oecologia 148:1-11. DOI:

$462 \quad 10.1007 / \mathrm{s} 00442-005-0350-7$

463

464 Scantlebury M., Krackow S. Pillay N., Bennett N., Schradin C., 2010. Basking is affected by 465 season and influences oxygen consumption in desert-living striped mice. Journal of Zoology 466 281:132-139. DOI: 10.1111/j.1469-7998.2010.00687.x

467

468 Schradin, C., Pillay, N., 2004. The Striped Mouse (Rhabdomys pumilio) from the succulent 469 karoo, South Africa: a territorial group-living solitary forager with communal breeding and 470 helpers at the nest. Journal of Comparative Psychology, 118(1):37-47. DOI: 10.1037/0735$471 \quad 7036.118 .1 .37$

472

473 Schradin C., Krackow S., Schubert M., Keller C., Schradin B., Pillay N., 2007. Regulation of 474 activity in desert-living striped mice: the importance of basking. Ethology 113:606-614. DOI: $475 \quad 10.1111 / \mathrm{j} .1439-0310.2007 .01361 . x$

476

477 Schwarzkopf, L., Shine, R., 1991. Thermal biology of reproduction in viviparous skinks, 478 Eulamprus tympanum: why do gravid females bask more? Oecologia, 88(4):562-569. DOI: 479

480 Stannard H.J., Fabian M., Old J.M., 2015. To bask or not to bask: Behavioural 
481 thermoregulation in two species of dasyurid. Phascogale calura and Antechinomys laniger.

482 Journal of Thermal Biology 53:66-71. DOI: 10.1007/BF00317720.

483

484 Stelzner, J. K., Hausfater, G., 1986. Posture, microclimate, and thermoregulation in yellow 485 baboons. Primates, 27(4):449-463.

486

487 Stevens, M. (2007). Predator perception and the interrelation between different forms of

488 protective coloration. Proceedings of the Royal Society B: Biological Sciences, 274(1617),

489 1457-1464. DOI: 10.1098/rspb.2007.0220

490 Terrien J., Perret M., Aujard F., 2011. Behavioral thermoregulation in mammals: a

491 review. Frontiers in Biosciences, 16:1428-1444. DOI: 10.2741/3797

492

493 Webb, J. K., Whiting, M. J., 2005. Why don't small snakes bask? Juvenile broad-headed

494 snakes trade thermal benefits for safety. Oikos, 110(3):515-522. DOI: 10.1111/j.0030-

$495 \quad 1299.2005 .13722 . x$

496

497 Viles, H. A., 2005. Microclimate and weathering in the central Namib Desert, Namibia.

498 Geomorphology, 67(1-2):189-209. DOI: 10.1016/j.geomorph.2004.04.006 
502 Figure 1. Temperatures at basking spots and two random locations, $20 \mathrm{~cm}$ away at the same

503 bush as a basking spot and $20 \mathrm{~cm}$ away to the front of a basking spot. Values represent mean

504 temperatures $\pm \mathrm{SE}$ in the morning (AM) and afternoon (PM). 
Table 1a. The statistical output of the temperature of basking and random spots in the

507 morning depending on the season (dry or moist) and minimum daily temperature. Intercept is

508 temperature at basking spot in the in the dry season. Significant variables are shown in bold.

\begin{tabular}{|l|r|r|r|r|}
\hline & Estimate & SE & t & P \\
\hline Intercept & $\mathbf{1 6 . 1 7}$ & $\mathbf{0 . 5 9}$ & $\mathbf{2 7 . 2 5}$ & $<\mathbf{0 . 0 0 1}$ \\
\hline Front & $\mathbf{- 1 . 9 3}$ & $\mathbf{0 . 1 4}$ & $\mathbf{- 1 3 . 8 2}$ & $<\mathbf{0 . 0 0 1}$ \\
\hline Right & $\mathbf{- 1 . 0 9}$ & $\mathbf{0 . 1 4}$ & $\mathbf{- 7 . 7 7}$ & $<\mathbf{0 . 0 0 1}$ \\
\hline Season (moist) & & & & 0.90 \\
\hline Minimum daily temperature & $\mathbf{- 0 . 0 8}$ & 0.69 & -0.12 & $<\mathbf{0 . 0 0 1}$ \\
\hline
\end{tabular}

509

510

511 
513 in the afternoon depending on the season (dry or moist) and minimum daily temperature.

514 Intercept is temperature at basking spot in the in the dry season. Significant variables are 515 shown in bold.

516

\begin{tabular}{|l|r|r|r|r|}
\hline & Estimate & SE & t & P \\
\hline Intercept & $\mathbf{2 7 . 3 0}$ & $\mathbf{0 . 9 6}$ & $\mathbf{2 8 . 3 8}$ & $<\mathbf{0 . 0 0 1}$ \\
\hline Front & $\mathbf{- 1 . 9 9}$ & $\mathbf{0 . 1 9}$ & $\mathbf{- 1 0 . 6 6}$ & $<\mathbf{0 . 0 0 1}$ \\
\hline Right & $\mathbf{- 1 . 0 6}$ & $\mathbf{0 . 1 9}$ & $\mathbf{- 5 . 7 1}$ & $<\mathbf{0 . 0 0 1}$ \\
\hline Season (moist) & 2.14 & 1.33 & 1.61 & 0.11 \\
\hline Minimum daily temperature & $\mathbf{0 . 4 5}$ & $\mathbf{0 . 0 9}$ & $\mathbf{5 . 1 0}$ & $<\mathbf{0 . 0 0 1}$ \\
\hline
\end{tabular}


518 ttemperature $(\Delta \mathrm{T})$ depending by season (dry or moist), minimum daily temperature and time

519 of the day: morning (am) or afternoon (pm). Intercept is $\Delta \mathrm{T}$ in the morning (am) in the dry

520 season.

521

\begin{tabular}{|l|r|r|r|r|}
\hline Response variable $=\Delta \mathrm{T}$ & Estimate & \multicolumn{1}{|l|}{$\mathrm{SE}$} & $\mathrm{t}$ & $\mathrm{P}$ \\
\hline Intercept & $\mathbf{1 . 5 1}$ & $\mathbf{0 . 3 7}$ & $\mathbf{4 . 1 4}$ & $<\mathbf{0 . 0 0 1}$ \\
\hline Minimum daily temperature & -0.04 & 0.02 & -1.56 & 0.12 \\
\hline Season (moist) & -0.24 & 0.22 & -1.06 & 0.29 \\
\hline Time (pm) & 0.16 & 0.34 & 0.49 & 0.62 \\
\hline
\end{tabular}

522 